\title{
EMANCIPATION OF WOMEN IN PHYSICAL EDUCATION PAPER ON HISTORY OF THE WOMEN'S UNIT OF SOKOL BRNO I (1902-1934)
}

\author{
MILENA S T R A C H O V Á
}

\begin{abstract}
STRACHOVÁ, Milena. Emancipation of women in physical education. Paper on history of the women's unit of Sokol Brno I (1902-1934). Historický časopis, 2019, 67, 2, pp. 265-288, Bratislava.

This paper deals with the foundation of the Sokol organization in Brno. However, the main focus is put on the origins of exercise in the Sokol Brno I women's units that were the biggest and the oldest unions in Moravia. The paper analyses the origins of the emancipation movement of Czech women at the beginning of the 20th century, in relation to two culture centres (Prague and Brno). Among others, it recalls a significant period of Brno's cultural history before World War 1 from two points of view: the development of physical education and the origins of the Brno women's movement. Obstacles that often impeded the enforcement of progressive thoughts are depicted. Prague was the leading city of Czech national life in the 19th century. However, it could not become a central point for Moravia due to the distance factor. Therefore, Brno adopted this role, although its situation was more complicated, as its population was mostly German at that time. And the German population did not support the origin of Czech national emancipation. The Sokol movement was not an exception in the process of gradual delimitation mostly against the Germans in progress since 1860 which eventually led to national liberation and independence. Key words: Physical education. Union Sokol Brno I. Women's emancipation movement. Moravia, Sokol movement.
\end{abstract}

DOI: https://doi.org/10.31577/histcaso.2019.67.2.4

Sokol Brno I, the biggest and oldest union from Brno, commemorated the very beginnings of exercising of women's units in 1934 and a remarkable collection of proceedings was put together on that occasion including contributions from several members of the union and some excerpts from the daily press. ${ }^{1}$ This

1 Moravský zemský archiv Brno [Archives of Moravian Lands in Brno] (hereinafter MZA), fond G Sokol krajský výbor - Brno, k. 39, i č. 315. URBÁNKOVÁ, Libuše - WURMOVÁ, Milada. G 106 Krajský výbor SOKOLA Brno 1873-1953 [G 106 Regional Committee of SO- 
collection is now deposited in the Archives of the Moravian Lands in Brno, and for a long time it was the only piece of work attempting to map the origins of the activities of the women's unit of Sokol Brno I. So far, this archival material related to the origins of the women's unit of Sokol Brno I has been subject to hardly any analytical research. Archival documents separated into several collections, stored either in the already mentioned Archives of the Moravian Lands or Archives of the City of Brno, represent the available sources for research. Most are stored in the Archives of the City of Brno where they constitute the R 77 Fund, Sports Union Brno I 1862-2008² containing diverse documents (including numerous photos), written documents from the registration office of Sokol, but also the library of the union. Despite the availability of numerous sources for the history of the women's unit of Sokol Brno I, the set of sources is not complete. Collecting and processing of sources thus constitutes the starting point for a more demanding research task. The scarce historiographic production focusing on the female emancipation movement in Sokol Brno calls for a mapping of the origins of the women's section of Sokol Brno in a broader context. ${ }^{3}$

Physical education of women was not accepted with much understanding in the past, despite the fact that it was and is equally important for women as for men. Before the founding of Sokol, women were not taken care of in this regard in the Czech Lands either. Miroslav Tyrš was aware of the importance of physical education for women and was therefore reflecting on how to include women in the restoration movement from the very beginning of Sokol's activities. They could not become directly involved in Sokol, as it was founded as a purely male club. ${ }^{4}$ This was caused by the unequal position of women in the society, but also

KOL Brno]. Brno, 1960, inventární číslo 23.

2 ČERMÁKOVÁ, Jana. Brno v minulosti a dnes [Brno in the past and today]. In Fondy a sbirky Archivu města Brna, 2006, year 19, p. 521.

3 Most recent contributions to the issue of female emancipation in sports by WAIC, Marek. Tělovýchova a sport ve službách české národní emancipace [Physical education and sports in the services of Czech national emancipation]. Praha: Karolinum, 2014, 69. ISBN 9788024622590; SCHŮTOVÁ, Jitka - WAIC, Marek. Tělesná výchova a sport žen v českých a dalšich středoevropských zemích: vznik a vývoj do druhé světové války = Turnen und Sport der Frauen in den böhmischen und anderen mitteleuropäischen Ländern: Entstehung und Entwicklung bis zum zweiten Weltkrieg [Physical education and sports for women in Bohemian and other other Cenral-European lands: origins and development until World War II]. Praha: Národní muzeum, 2003, p. 169-190. ISBN 8070361581; KLÍMOVÁ, Eliška. Postavení žen v Sokole Brno I. 1902-1915 [Position of women in Sokol Brno I. 1902-1915]: Bakalářská práce. Brno: Masarykova Univerzita, 2010.

4 Tyrš developped the Sokol idea on three pillars, as defined by Arne Novák, expert on the history of literature - "national romanism of the German Turnen movement", "symmetrical and harmonious ideal of the Greek kalokagathia" and "patriotic liberalism", see NOVÁK, Jan Václav - NOVÁK, Arne. Přehledné dějiny literatury české od nejstaršich dob až po naše dny 
by efforts to avoid closer contact between women and men. Also, women would not want to be involved in such a club for fear of losing their good name and to avoid causing public outrage. ${ }^{5}$ Too many religious and social prejudices still prevailed in the 19th century, and even progressive men and women were not able to dissociate themselves from that. This phenomenon was best captured by Míla Koutníková: “...physical exercise for girls is improper, a woman only needs to be a good housewife..." 6

Miroslav Tyrš therefore found another option for physical education of women which was also in line with the Sokol principals. The management report from March 1866 is a proof that he had been considering this solution for a long time: "Our chief dr. Tyrš set the task to train a team of female instructors in his institute of physical education, so that the control over female physical education can gradually be handed over to women, and thus achieve an ease participation of older ladies in physical exercises. " A private Institute of Physical Education for Boys and Girls had been active in the sokolovna building of Sokol Prague since 1863, headed at first by the orthopaedic doctor Jan Musil, as Sokol Prague itself did not receive the authorization to train children or students. Later, after Jan Musil left for Teplice to work as a spa doctor, Miroslav Tyrš took over the training of girls. The number of girl gymnasts varied, often there were just two of them exercising under the guidance of Tyrš. That probably inspired Tyrš to the idea of common lessons for women and girls guided by female instructors. ${ }^{7}$ From January 1866 Tyrš was training older girls (who respected, or even feared „the doctor“ a lot, as we know from Teréza Nováková), and by the end of 1866 ,

[Czech literature history overview from the oldest times until today]. Brno: Atlantis, 1995, p. 595. ISBN 8071081051. The issue of the second pillar was best explained by Robert Sak in his work on Miroslav Tyrš “...the antique period attracted him by its ideal of happiness ... ancient Greece presented for Tyrš (and also for Jan Evangelista Purkyně, Ignác Jan Hanuš, Jan and Ctibor Helcelet) the model of dignified humanism, the ideal of the harmonious man and conscious citizen...". SAK, Robert. Miroslav Tyrš: sokol, myslitel, výtvarný kritik [Miroslav Tyrš: member of Sokol, thinker, art critic]. Praha: Vyšehrad: Česká obec sokolská, 2012, p. 65. ISBN 9788074292392; WAIC, Marek. Télovýchova a sport [Physical education and sports]. Praha: Karolinum, 2013, p. 54. ISBN 9788024622590.

5 WAITOVÁ, Miluše. Vzpomínáme počátků ženského tělocviku [Remembering the beginnings of physical education for women]. In Sokolský věstník: list Československé obce sokolské, 1948, year 46, no. 43-44, p. 574. Compare with BLÁHA, Filip. Úloha Tělocvičného spolku paní a dívek pražských v emancipačním hnutí českých žen před první světovou válkou [The role of the Physical Education Club for Prague ladies and girls in the emancipation movement before World War I]. In SCHU゚TOVÁ - WAIC, ref. 3, p. 7-8. ISBN 8070361581.

6 KOUTNÍKOVÁ, Míla. Žena v Sokole [Women in Sokol]. In Věstník sokolský, 1913, year 17, p. 6.

7 WAIC, ref. 4, s. 53-54. BLÁHA, Filip. Úloha Tělocvičného spolku [The role of the Physical Education Club]. Praha: Národní museum, 2003, s. 13. ISBN 8070361581. 
he had trained seven future female gymnastics instructors. ${ }^{8}$ Ctibor Helcelet, who later became chief of the Brno union and who was living in the household of Ignác Jan Hanuš, former professor of philosophy and director of the university library, recommended the daughters of Hanuš, Dora and Klementina, to Tyrš. They were "experienced devotees of physical education", as it was said that everybody was working out ${ }^{9}$ in their household, as we know from Teréza Nováková. Tyrš considered the younger, 24-years old Klemeňa, ${ }^{10}$ as she was called, to be the best of all gymnasts, as she was "intelligent and educated enough to understand what a leading instructor of physical education for women should know". ${ }^{11}$ In the biography of Renáta Tyršová, Irena Štěpánová presented an opinion on Miss Hanušová: "We girls were impressed by her performance, but somehow we could not warm to her." 12

Miroslav Tyrš was a supporter of the emancipation idea of Czech women, which is demonstrated by the fact that Eliška Krásnohorská, writer and promoter of the emancipation movement of Czech women, counted him among her dearest friends. Their relations however were not based on the Sokol idea, but on aesthetics, literature and approach to the female issue. She considered him to be one of the first determined male feminists she had met in her life, if not the very first one.

It was mainly his approach to the female issue that incited her friendship, and that is probably why she took down his statements: "Woman is the crown of all beings" and "Women are the better and more valuable half of humankind". ${ }^{13}$

8 SAK, Robert. Miroslav Tyrš: sokol, myslitel, výtvarný kritik [Miroslav Tyrš: member of Sokol, thinker, art critic] Praha: Vyšehrad: Česká obec sokolská, 2012, s. 80-81. ISBN 9788074292392; SCHŮTOVÁ, Jitka. Ženy v Sokole [Women in Sokol]. In SCHU゚TOVÁ, WAIC, ref. 3, p. 67. ISBN 8070361581; WAIC, ref. 4, p. 54.

9 NOVÁKOVÁ, Teréza. Staré upomínky sokolské [Old Sokol memories]. In JANDÁSEK, Ladislav (ed.). Vzpomínky na Dr. Mir. Tyrše. Praha: b.m., 1934, p. 117.

10 Klementina (Klemeňa) Hanušová (* 19 March 1845 Lvov, $\uparrow 7$ October 1918 Prague) was a Czech teacher of physical education and expert writer. More information about the person In VOŠAHLÍKOVÁ, Pavla - MARTÍNEK, Jiří. Cesty $k$ samostatnosti: portréty ženy v ére modernizace [Routes to independence: portraits of women in the modernization era]. Praha: Historický ústav AV ČR, 2010, p. 62-69. ISBN 9788072861644.

11 TYRŠOVÁ, Renáta. Miroslav Tyrš, jeho osobnost a dílo: podle zápisků, korespondence, rukopisné pozůstalosti a mých vzpomínek I [Miroslav Tyrš, his personality and work: based on notes, correspondence, manuscripts and my memories I]. Praha: Český čtenáŕ, 1932, p. 87; WACHTLOVÁ, Markéta. Dílo Klemeni Hanušové [Work of Klemeňa Hanušová]. Praha: b.m., 1948, p. 16.

12 ŠTĚPÁNOVÁ, Irena. Renáta Tyršová. Praha; Litomyšl: Paseka, 2005, p. 64. ISBN 8071856932.

13 KRÁSNOHORSKÁ, Eliška. Ze vzpomínek [Based on memories]. In JANDÁSEK, Ladislav (ed.). Vzpominky na Dr. Mir. Tyrše. Praha: b.m., 1934, p. 112. 
Tyrš was persuaded that women should decide for themselves how to perform physical education. Therefore, he proposed during a conversation with Kateřina Fügnerová that it would be good to set up a club of physical activities following the model of the first female turnen club in Berlin, active since 1860. Madame Katerina liked the idea of a club that would be managed by women themselves, but she refused the offered position of its leader. She agreed however to chair the preparatory committee. Based on this impulse from Tyrš, several Czech women met on 23 July 1869 at Mrs. Fügnerová's to discuss the setting up of a physical education club for women. Miroslav Tyrš, who saw Renáta Fügnerová as one of the future gymnastics instructors, was actively helping in the preparation and also drafted the statutes that were approved in September of the same year. After approval of the statutes of the Physical Education Club for Prague Ladies and Girls by the authorities, the club could start its functioning. ${ }^{14}$ Exactly two months later, the General Assembly in the Sokolovna building elected as leader Sofie Podlipská, a writer that Tyrš knew from various public events and from the "salon" society meetings of Vojta Náprstek, and Anna Srbová was elected deputy leader. Klementina Hanušová was given the task of forming a team of female instructors. The pioneering club received support from Karolina Světlá, Betty Smetanová and other ladies. Teréza Lanhausová (later married Nováková) proposed to the girls to address each other using the informal thou and call each other "sisters". ${ }^{15}$

The example of Brno clearly shows how the destinies of individual Sokol unions were taking varied routes. The reasons behind the varied development were best explained by Marek Waic who speaks about unions in his work: "It depended on local conditions, ...on the activity and self-sacrifice of individuals. "16 Despite the difficult beginnings, Sokol Brno I directly helped with the setting up of numerous other Moravian unions or even founded them directly. It played the leading role in the Rastislavova župa (administrative district), later called župa Jana Máchala. ${ }^{17}$ Czech patriots, motivated by the setting up of a German physical education union in Brno (Turnverein) and its recruitment of gymnasts (German

14 WAITOVÁ, ref. 5, p. 112; WAIC, ref. 4, p. 55-56; BLÁHA, ref. 7, p. 14.

15 SAK, ref. 8, p. 82; NOVÁKOVÁ, ref. 9, p. 119.

16 WAIC, ref. 4, p. 42. Germans often accusing Czechs of imitating and downplaying German cultural progress. That was based on the refusal to have clubs divided based on nationality Moravian Germans perceived this as a betrayal of German leadership. At the same time, they were blankly refusing the requests of each ethnic group for their own culture and education. Červená, Radana. Počátky brněnského Sokola a jeho zakladatelé [Beginnings of Sokol Brno and its founders]. In Sborník přispěvki̊ k dějinám a výstavbě Brna (BMD), 2005, no. 18, p. 223. ISBN 8086736016.

17 This applies only after the Rastislavova župa was divided in 1913 into two - Brněnská župa and župa Jana Máchala. 
press on 8 January 1862), proceeded to the creation of a Czech physical education union. Thus, on 12 January 1862, the German "Neuigkeiten"18 published information about the preparations to set up an independent Slavic physical education union (Physical Education Union in Brno), with more than 60 candidates applying for membership. The Brno union was thus founded at about the same time as the "Physical Education Union in Prague" which only started with exercising two months after the Brno union. ${ }^{19}$

The Brno union ceased to exist for some time in February 1867 but was restarted again quite soon (23 September 1868). The announcing of the Austro-Hungarian dualism, introduced after the defeat of Austria in the war with Prussia, might have been a major impulse. The dualistic arrangement of state power brought about a wave of disillusionment to Czech national politics and a tangible reduction of loyalty towards the Habsburg throne. As Bohemia, the representatives of Czech public life in Moravia tried to revive the Czech emancipation efforts. ${ }^{20}$ After its re-opening, members of the Brno union elected as their leader Josef Fandrlík, an important deputy of the Assembly of the Moravian Lands and of the Imperial Council, but the driving force of the union was Ctibor Helcelet, its Chief. His father belonged to the closest circle of friends of the writer Božena Němcová. Ctibor's ambition was to develop the Brno union into a leading centre for the Moravian members of the Sokol movement, similarly to what the Prague union represented for Sokol movement members in Bohemia. He tried to unite all the Sokol unions in the Czech Lands from Brno. ${ }^{21}$ Nevertheless, the mental distance between Prague and Brno was much more substantial in the 1870s than today. This is best documented by the fact that there was no response in Moravia to the founding of the Physical Education Club for Prague Ladies and Girls on 15 November 1869, despite the important role women had played in Brno since the very beginnings of the physical education union. Again, their role is best demonstrated by the fact that there was a ceremony of consecration of the Sokol flag gifted by Czech female patriots ${ }^{22}$ which took place in Brno on 30 May

18 Brünner Zuschauer. Neuigkeiten, year 12, no. 11, from 12 Jan 1862, p. 1.

19 The first exercises took place in Sokol Brno already on 15 January 1862. The Statutes were approved only on 2 December 1862 and this date is considered as the day when the union was founded. ZAPLETAL, Vladimír - KOŽÍK, František. Dějiny Sokola Brno I 1862-1887 [History of Sokol Brno I 1862-1887]. Brno: Sokol Brno I, 1948, p. 18-22. Compare with WAIC, ref. 4, p. 26; ČERVENÁ, ref. 16, p. 217-257.

20 WAIC, ref. 4 , p. 36

21 SAK, ref. 8, p. 110.

22 DOLEŽEL, Michal et al. Prapor Sokola Brno I [Flag of Sokol Brno I]. Brno: Sokol Brno I, 2015, p. 17-20. ISBN 9788027015689; BURIAN, Václav. Svěcení praporu „Sokola“v Brně roku 1871 [Sanctification of the "Sokol" flag in Brno in 1871]. In Vlastivědný věstník moravský, 1995, year 47, no. 2, p. 128-135. 
1871 on the Ratvítovo Square ${ }^{23}$ in front of the Protestant church (where the old Lands House (zemský dům) stands today). When singers from Brno finished the song Ktož sú boži bojovnící (Ye Who Are Warriors of God), the flag was approached by its mother, Mrs Marie Dvoŕáková ${ }^{24}$ with twelve godmothers: Ladislava Kuncová, Antonie Hurychová, Lvislava Rudišová and Žofie Rudišová, Adéla Valterová, Milada Zelená, Hermína Hlávková, Luisa Olivová, Amalie Teplá, Žofie Zedníková and Antonie Svobodová. ${ }^{25}$ The mother of the flag then spoke to the people and hammered the pin into the flagpole. She was followed by all the godmothers who recited mottos of Sokol: bravery, perseverance, vigour, courage, enthusiasm, unity, hardiness, sincerity, vigilance, nobility, liberty, fraternity, everything for the mother land! ${ }^{26}$

Florián Zedník, leader of Sokol Brno, mentioned the importance of the ceremony, thanked for participation and finished his speech applauded by all the present people using the words: "Your participation at the ceremony today gave it even more importance, thus being the proof that where a Moravian is standing, a courageous Bohemian brother and a brave Silesian are also present ..." Subsequently, the colour bearer raised the new flag. The consecration ceremony was followed by an afternoon event in the U Marovského pub (part of the National Theatre building in the Veveři Street $)^{27}$ and by an evening ball for the society in

23 Radwitplatz, Radwitovo or Raduitovo square (today's Žerotínovo square). FLODROVÁ, Milena. Brněnské ulice a vývoj jejich názvĩ od 13. století po dnešek [Streets of Brno and development of their names from the 13th century until today]. Brno: Magistrát města Brna, 1997, p. 288.

24 Marie Dvoř́ḱková (* 15. 3. 1848 Brno, † 3. 6. 1880) was the second daughter born to Jan Hlávka, factory owner from Brno and wife of the Reichsrat deputy and editor of the Moravská orlice paper Jindřich Dvoř́k. At that time, she was the only representative of the female world in the Brno social life. As an educated and well-off patriot, she became the leader of the newly founded Vesna. More information about the person In ZAPLETAL, Vladimír - KOŽÍI, František. Déjiny Sokola [History of Sokol]. Brno: Sokol Brno I, 1948, p. 80.

25 Zorka Klosová commented on that in 1932: "Mrs. Dvoř́k ková was the mother of the flag, the names of the twelve godmothers are unfortunately not known." MZA, fond G 106 města Brna, k. 224, Výroční zprávy Brna I. 1869-1947 [Annual Reports Brno I. 1869-1947]. KLOSOVÁ, Zorka. Jak jsme začínaly [How we began]. In Zprávy Sokola Brno I, 1932, year 8, no. 9, p. 176.

26 Archiv města Brna [Archives of the City of Brno] (hereinafter AMB), fond R 77 Sokol, Sdružení tělesné výchovy Brna I [Physical education union Brno I 1862-2008] (hereinafter fond R 77), N 1, inventární číslo 1518, Upomínka na jubilejni slavnost Tělocvičné jednoty Brněnské ,,SOKOL "1862-1887 [Remembering the jubilee event of the Physical education union "SOKOL" Brno 1862-1887], Brno 1887, p. 7.

27 The setting up of the Na Veveři theatre meant that the long-term longing of the patriotic citizens of Brno to have their own Czech theatre was finally satisfied, at least partially. The house No 6 on Radvítovo square, called "U Marovských" was built in 1840 and originally served as the dance hall Orfeum or as the so-called Viennese restaurant. For more information see PE- 
Lužánky and fireworks in the park attended by 5,000 persons. ${ }^{28}$ It was undoubtedly an important ceremony in that time, as it was attended by 1,062 members from fifty unions from Bohemia and twelve from Moravia as well as by the Viceregent Count Sigmund Thun ${ }^{29}$ himself with all councillors, and many ordinary people (approx. 30,000). The aim was not merely to show support, but to express a brave acknowledgement of the Sokol idea. It was the biggest rally of Czech and Moravian Sokol clubs so far and led to the idea of Sokol movement unification. Therefore Ctibor Helcelet, Jan Rychman and Jan Strnad summoned a meeting of Moravian unions delegates for 8 December 1871, where the Sokol headquarters were set up and subsequently the first Sokol župa in Moravia was created. ${ }^{30}$ The efforts of Helcelet led to a dispute, where Tyrš in principle was not against Helcelet's idea to have the centre of the Moravian Sokol movement in Brno, but he did not believe Helcelet would be able to "hoodwink/" the Vienna government, and he also did not hide his doubts about Brno having enough members able to work in responsible functions. Tyrš informed Helcelet about what was being prepared in Prague in mutual correspondence and he insisted that it was not possible to

CHOVÁ, Ema. Padesát minus jedna [Fifty minus one]. In NESTROJ, František (ed.). Zlatá kniha vydaná Družstvem českého národního divadla v jubilejním roce 1934 na oslavu 50letého trváni stálého českého divadla v Brně ve vlastní budově na Veveři. Brno: Družstvo českého národního divadla, 1934, p. 108; KROUPA et al. Déjiny Brna 7: Uměleckohistorické památky, historické jádro [History of Brno No 7, Artistic and historical monuments, historical city centre]. Brno: Statutární město Brno: Archviv města Brna, 2015, p. 655. ISBN 9788086736464.

28 ZAPLETAL, Vladimír - KOŽÍIK, František. Dějiny Sokola. Brno: Sokol Brno I, 1948, p. 54; BULÍN, Hynek. Besedni di̊m v Brně 1872-1922 [Besední dům building in Brno 1872-1922]. Brno: b.m., 1922, p. 14. Municipal Park Lužánky see KROUPA et al. Dějiny Brna 7: Uméleckohistorické památky, historické jádro [History of Brno No 7, Artistic and historical monuments, historical city centre]. Brno: Statutární město Brno: Archviv města Brna, 2015, p. 767-773. ISBN 9788086736464.

29 Sigmund Ignaz Thun-Hohenstein (* 11 June 1827 in Klášterec nad Ohř́, † 7 September 1897 Salzburg) was a deputy in the Bohemian Lands Assembly, Moravian Vice-regent and Minister-President of the Salzburg Land. More information about the person In VYSKOČIL, Aleš. Slovník predstavitelů politické správy na Moravě v letech 1850-1918 [Dictionary of political administration representatives in Moravia in the years 1850-1918]. Praha: Historický ústav, 2011, p. 291-292. ISBN 9788072861835.

30 MZA, fond G 106 města Brna, k. 224, Výroční zprávy Brna I. 1869-1947 [Annual Reports Brno I. 1869-1947]; KLOSOVÁ, ref. 25, p. 176; ROUBÍČKOVÁ, Renata. Ženy v dějinách naši jednoty [Women in the history of our union]. In Vzpomínáme 75 let Sokola Brno I. Brno: b.m., 1937, p. 20-22; ČERVENÁ, Radana. Vybudování stadionu Sokola Brno I: Sokolské tělocvičny v letech 1862-1929 [Building the stadium of Sokol Brno I. Sokol Gymnasiums in the years 1862-1929] In Sborník přispěvků k dějinám a výstavbě Brna (BMD), no. 21, 2008, p. 181-205. ISBN 9788086736105; ČERVENÁ, ref. 16, p. 232. One should note that nine new Sokol unions were founded following the event: Královo Pole, Morkovice, Rousínov, Uherské Hradiště, Podivín, Frenštát, Dačice, Kyjov, Ruprechtov, Velká Bystřice. Doležal, ref. 22, p. 18. 
hold two rallies in one year. He also announced in a dry manner that he would not attend the consecration ceremony in Brno and indeed he kept his word, only sending a written salute. ${ }^{31}$ Similarly, the then mayor of Brno, Christian D'Elvert, also refused to attend the ceremony using the following words: "...Brno being a German city, he as the top representative cannot participate in a Slavic ceremony. ",32

The undisputed influence of Brno women on the presentation of Sokol Brno I can be observed also in the years that followed. During the period before the III. Sokol slet (rally) in Prague, connected with to the Ethnographic Exhibition of Czechoslavic People where the Brno union was expected to participate, a committee of women and ladies was set up chaired by Luisa Nováková and Adéla Koudelová, leader of the Brno Vesna club, with the objective to acquire a new solemn flag for the Physical Education Union Sokol Brno I. The flag design was prepared by Zdenka Vorlová - Vlčková, a collaborator of music composer Leoš Janáček and architect Dušan Jurkovič. The ceremonial presentation of the flag took place on 12 May 1895 in the Big Hall of the Besední dům building. ${ }^{33}$

The enthusiasm for founding of women's clubs active in various areas (social, cultural, educational etc) was a visible sign of the approach and attitude of Brno women. Several German clubs were active in Brno before WWI, aimed at different areas. The Brno Women's Manufacturing Club focusing on education of girls and ladies following German traditions had the strongest position. In addition, information on further requirements by women related to the organization of their life and the life of the entire society started arriving to Brno after 1900 from Bohemia but also from abroad. ${ }^{34}$ The first brief mention of the female unit

31 SAK, ref. 8, p. 110; GROH, Vladimír et al. Dopisy dr. Miroslava Tyrše Ctiboru Helceletovi [Letters of dr. Miroslav Tyrš to Ctibor Helcelet]. Praha: Nakladatelství České obce sokolské, 1940, p. 26-28. Letters date 31 July 1869 and 16 March 1871. For information on the approach of Tyrš to ceremonies and events see TYRŠ, Miroslav. O sokolské idei II [About the Sokol idea II]. Praha: b.m., 1931, p. 144-145.

32 AMB, fond R 77 města Brna, inventární číslo 1518. Protocol of the Administrative Committee on the meetings and general assemblies of the club in 1900-1904, Minutes of the Committee meeting from 1 October 1901. It was only in June 1902 when the board of the Sokol community decided to integrate the Physical education club for Prague ladies and girls into the Czechoslovak Sokol Community. WAIC, ref 4, p. 60.

33 DOLEŽEL, ref. 22, p. 21-22.

34 BEDNÁŘOVÁ, Věra. Př́spěvek $k$ dějinám brněnského školství: počátky divčího středního školstvi v Brně [Contribution to the history of education in Brno: Beginnings of secondary schooling for girls in Brno]. In Sborník přispěvků k dějinám a výstavbě Brna (BMD), 1970, no. 9, p. 35. ISBN 9788086736105; CIBULKA, Pavel. Politizace německého ženského hnutí v Brně před první světovou válkou [Politicization of the German women's movement in Brno before World War I]. In BAHENSKÁ, Marie - MALÍNSKÁ, Jana (eds.). Ženy a politika 1890-1938. Praha: Masarykův ústav a Archiv AV ČR, 2014, p. 144-168. ISBN 
of physical education dates from 1896 - the annual report says: "Female unit of physical education (in the Besedni dim building) not in place yet due to various obstacles. " 35 A guideline was still in force in Sokol that year not allowing women to join Sokol unions. After the success of the first public performance in 1898, the General Assembly of the Czech Sokol Community approved the setting up of women's units in Sokol unions with their own management, but still dependent on the union. ${ }^{36}$ Changes occurred only after the VI. Pan-Sokol slet in Prague in 1901 where the performance of exercising women was very successful. That was a motivation also for Sokol Brno I to act and start the preparations for setting up of a women's unit: "Ešner proposed to proceed to setting up of a separate female unit, independent on the physical education unit Vesna. "37 The instructors' team prepared a proposal according to which the women's unit would elect the chair, chief and treasurer itself, and at the same time one member of the administrative committee would attend the committee meetings of the unit (this supervisory task was entrusted to František Ešner who was also supposed to lead the exercises at the beginning). Already then, the union had high expectations regarding the women's unit, even though it did not exist yet. ${ }^{38}$ Annual reports show that the "women's physical education unit" was set up at the meeting on 23 January 1902. Leader Josefa Fišová, deputy leader Emilie Ešnerová, agent Antonína Pouchlá and treasurer Krista Dobrá were elected at the constituent meeting. The position of Chief remained vacant, exercises were led by František Ešner. First exercises were to take place on 4 February 1902 and female members were accepted from the age of $14 .{ }^{39}$

9788087782248. At the end of 1897, the following Sokol unions already had women's departments in place: Vyšehrad, Staré město [Old Town], Smíchov, Menší Město pražské [Lesser City of Prague], Dobrovice, Horažd'ovice, Jindřichův Hradec, Humpolec, Chrudim, Kolín, Kladno, Klatovy, Kralupy, Liberec, Lomnice, Lovosice, Most, Pankrác, Nusle, Písek, Plzen̆, Slaný, Sušice, Tábor and Vysočany. KOUTNÍKOVÁ, Míla. Žena v Sokole [Woman in Sokol]. In Sokol Journal, year 17, no. 7 from 10 April 1913, p. 214-215.

35 AMB, fond R 77 města Brna, N 10, inventární číslo 1574, Výroční zprávy Sokola Brno I 1896-1910 [Annual Reports of Sokol Brno I 1896-1910], 1896, p. 8.

36 SCHŮTOVÁ, ref. 8, p. 69.

37 AMB, fond R 77 města Brna, inventární číslo 3. Protocol of the Administrative Committee on the meetings and general assemblies of the club in 1900-1904. It was only in June 1902 that the board of the Sokol community decided to integrate the Physical education club for Prague ladies and girls into the Czechoslovak Sokol Community. WAIC, ref. 4, p. 60.

38 "Even though the women's unit is not yet active as the preparatory works have not been concluded yet, we are hoping that the issue of female physical education will be well accepted by the ladies from Brno and that we will soon welcome them in our ranks." AMB, fond R 77 města Brna, N 10, inventární číslo 1574, Výroční zprávy Sokola Brno I 1896-1910 [Annual Reports of Sokol Brno I 1896-1910], 1901, p. 8-9.

39 AMB, fond R 77 města Brna, N 10, inventární číslo 1574, Výroční zprávy Sokola Brno I 


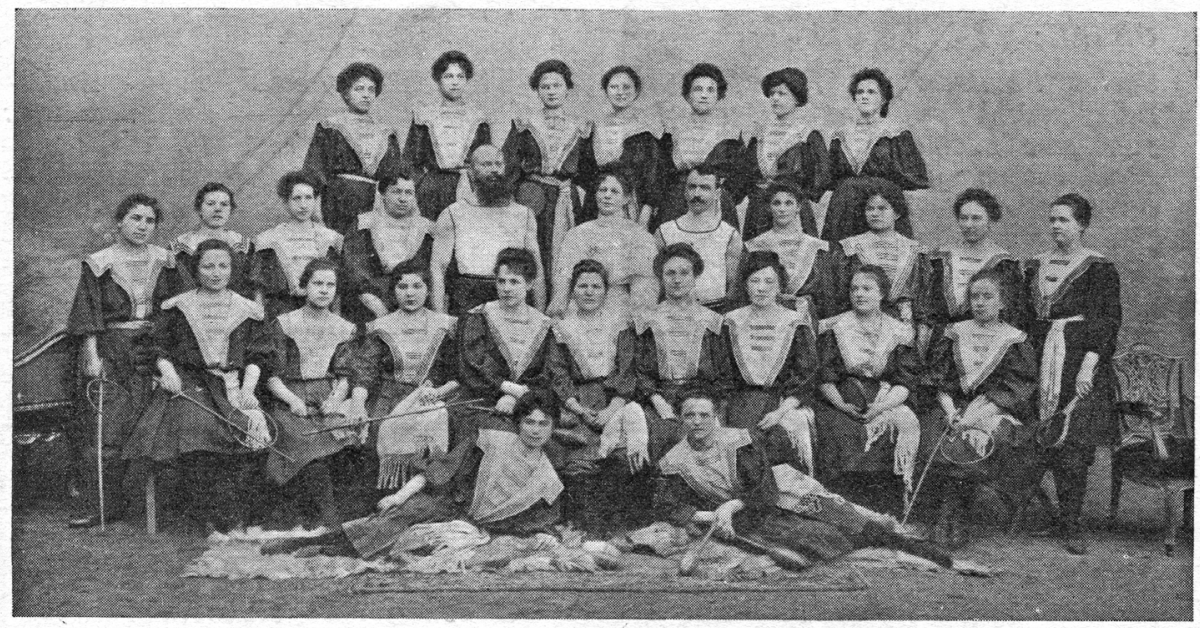

A1 First instructors' course of the CSC for women in 1902. MZA, fond G 106 města Brna, k. 370. Sokolice. List pro sokolskou výchovu žen [Sokolice. Journal for Sokol education of women], 1938, roč. 26, č. 1-2, s. 10.

The elected presidium held meetings in this composition in March, April and May. During the May meeting, a new Code of the women's unit was adopted which was approved by the Administrative Committee of the Union on 7 May 1902. Pursuant to Art. 3 of the Code, it was necessary to elect the full presidium, therefore an extraordinary meeting was summoned. Krista Trávníčková-Cohornová was elected as Chief of the unit and František Exner as technical leader. The instructors' team was trained by the Chief in function at that time, Cyril Hýlek. The women's unit was thus self-managing. ${ }^{40}$

There were several issues related to the functioning of the unit from the very beginning. One aspect that was unheard of at that time - monthly meetings of the Administrative Committee were taking place in the changing room at the same time as women were changing there before exercising. In November 1902, the women's unit asked the Administrative Committee to act and solve the complicated situation. The main reason behind the complaints of women was fear of the public, or more precisely of the possible repercussions if "the public found out

1896-1910 [Annual Report of Sokol Brno I 1896-1910], 1902, p. 16-19. For more information on the women's unit, see AMB, fond R 77 města Brna, N 70, inventární číslo 31, Zápisy ze zasedání ženské jednoty 1902-1904 [Minutes from the meetings of the women's unit 1902-1904], 1902, p. 8.

40 25. výročí ženského sokolského tělocviku v Brně [25th anniversary of Sokol physical education for women in Brno]. In Lidové noviny, year 42, no. 497 from 3 Oct 1934, p. 6. 
that undressing and dressing of female members and meeting of Administrative Committee members are taking place at the same time in one room ". ${ }^{41}$

This first attempt to set up physical education for women in Brno did not last, despite the fact that 24 women and girls signed up at the beginning and by the end of the year, the number even grew to 40 . Even the first public performance of women in April 1903 did not help, even though 24 women performed exercises with rods and games as part of the presentation of the union. Despite this, the unit stopped functioning on 31 May 1904 when the first chief Krista Trávníčková left. ${ }^{42}$ Most often, the internal conflicts within the women's unit were seen as the reason behind this. Krista Trávníčková herself, however, offers a slightly different explanation in her memoirs. She was persuaded that the women's unit was victim of an injustice - even though unintended - as the unit was not endangered that much by disputes, but more by the difficult situation in Germanized Brno. In addition, the time had not yet been progressive enough to accept Sokol activities performed by women, which only aggravated what would otherwise have been normal disputes. ${ }^{43}$

The period that followed the abolition of the women's unit was rather difficult for the union. When the women's unit started its activities, Brno was more a German city than a Czech one, and thus the initial position of Sokol was rather complicated. It was the German Liberal Party that controlled the city administration and had an impact on public affairs in the city. The beginnings of the Sokol movement in the strongly Germanized environment of Brno were linked to the fight for national independence and equality of languages. ${ }^{44}$

Shortly after the women's unit ceased to exist, a private society for ladies asked the Administrative Committee for the possibility to use regularly the gymnasium for exercises. They received a curt reply that the gymnasium will be full, with recommendation for "the society to follow the example of the German teach-

41 AMB, fond R 77 města Brna, inventární číslo 3. Protocol of the Administrative Committee on the meetings and general assemblies of the club in 1900-1904, Minutes of the Committee meeting from 7 November 1902.

42 AMB, fond R 77 města Brna, N 10, inventární číslo 1574, Výroční zprávy Sokola Brno I 1896-1910 [Annual Reports of Sokol Brno I 1896-1910], 1896, p. 9. Compare with MZA, fond G 106 města Brna, inventární číslo 39, k. 315. BABÁKOVÁ, Amalie. Vývoj činnosti ženského odboru Sokola Brno I [Development of activities of the women's unit of Sokol Brno I]. In Ženy Sokola Brno I. 1909-1934. Brno: b.m., 1934, p. 123. For more information on the reasons for the abolition of the women's unit see Klímová, ref. 3, p. 15-19.

43 MZA, fond G 106 města Brna, inventární číslo 39, k. 315; COHORNOVÁ TRÁVNIČKOVÁ, Krista. 25 let nepřetržité činnosti našich žen [25 years of continuous activities of our women]. In Sokol ženy Brno I 1909-1939. Brno: b.m., 1939, s. 4.

44 ŘÍHOVÁ, Hana. Ženská emancipace v českých zemích v 19. století s přihlédnutím k brněnskému spolku Vesna [Female emancipation in the Czech lands in the 19th century with regard to the Brno club Vesna]. Diplomová práce. Brno: Masarykova Univerzita, 2016. 
ers and negotiate permission to exercise in one of the gymnasiums in primary schools". The Vesna club was however still using the gymnasium for exercise by its female members. ${ }^{45}$ The 1906 Annual Report mentions changing rooms for women in the context of attempts to build a new gymnasium, which is a proof that the Brno union was still planning exercise for women in the future. ${ }^{46}$

Some members of the unit continued to contribute and later took part in the re-founding of the women's unit in $1909,{ }^{47}$ when physical exercises for women started again and this time for good. Women started exercising in September 1909, a month later they were joined for the first time by girl pupils and in November by female juniors. Anna Vodová was the driving force behind all this, not only as the organizer, but she was also leading all the sections and taking care of the leaders' training. She thus became the soul of the entire unit. As Amalie Babáková later put it in her work: "...for three years, she was the best leader of the women's unit...". ${ }^{48}$ Anna Vodová herself later remembered the reasons that led her to act: “...when I came to Brno in 1908, Rastislavova župa was among the first ones in the CSC, ...but women's units were merely surviving...., after a year of forced inactivity, my Sokol conscience was protesting therefore I felt it as my duty to offer my work and help. On 26 August 1909, I wrote to the male instructors' team of Brno I asking for the women's unit to be re-founded and offering my Sokol services to the union..." ${ }^{49}$ The charismatic and tireless Anna Vodová had a positive impact on her pupils, as demonstrated by words of Matilda Schafhauptová: "She became the leader of our exercises, but also ideas and feelings." ${ }_{50}$

45 AMB, fond R 77 města Brna, inventární číslo 4. Protocol of the Administrative Committee on the meetings and general assemblies of the club in 1904-1912, Minutes of the Committee meeting from 4 August 1904. AMB, fond R 77 města Brna, N 10, inventární číslo 1574, Výroční zprávy Sokola Brno I 1896-1910 [Annual Reports of Sokol Brno I 1896-1910], 1906-1909, p. 31

46 AMB, fond R 77 města Brna, N 10, inventární číslo 1574, Výroční zprávy Sokola Brno I 1896-1910 [Annual Reports of Sokol Brno I 1896-1910], 1906, p. 32.

47 The proposal of voting rights for women that was not accepted started an extensive debate on equality of womens' departments already in 1905. The issue of equality of female members with men, with equal rights and not only responsibilities, had been discussed since 1903 when the Committee of the Czechoslovak Sokol Community approved the Sokol Code for womens' departments that was binding for all unions. SCHŮTOVÁ, ref. 8, p. 70.

48 MZA, fond G 106 města Brna, inventární číslo 39, k. 315; BABÁKOVÁ, ref. 42, p. 123 compare with 25 let ženského odboru Sokola Brno I [ 25 years of the womens' unit of Sokol Brno I]. In Lidové noviny, year 42, no. 563 from 8 Nov 1934, p. 6.

49 Anna Vodová (* 15 June 1878 in Frenštát pod Radhoštěm, † 4 September 1957 in Brno) was a teacher of physical education and wife of Sylvestr Voda, an important member of Sokol Brno and the first military commander of Brno after creation of the Czechoslovak Republic. For more information about the person see VODOVÁ, Anna. Jak jsme začínaly [How we began]. In Ženy Sokola Brno I. 1909-1934. Brno: b.m., 1934, p. 127.

50 SCHAUFHAUPTOVÁ, Matilda. Hrst vzpomínek [Handfull of memories]. In Ženy Sokola 
The women's unit was marginally involved in the Exhibition of abstinence, organized on $10-24$ November 1912 by the educational department of Sokol together with the National Organization of Progressive Women. Twenty-four women participated in the exhibition that was accompanied by numerous lectures and took place in the halls at Lužánky. ${ }^{51}$

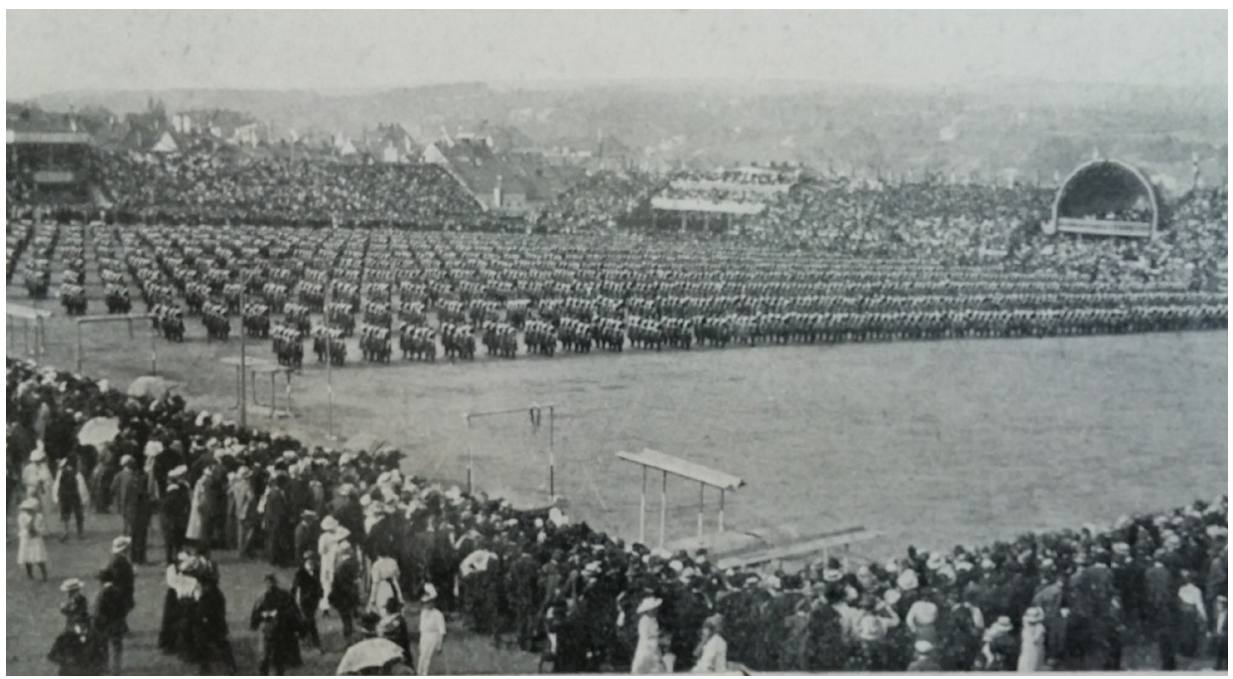

A2 Lining up of women for the parade at the slet in 1914. AMB, fond R 77 města Brna, N. 10, inventární číslo 709, k. 109. Tiskoviny 1914 [Press 1914], 1914, s. 13.

The number of female gymnasts continued to grow and it was therefore necessary to direct those women that had a serious interest in physical education to instructor schools. The first examination of female instructors took place in 1913, with 21 women from various unions participating. By expanding their technical knowledge, women were gradually becoming more independent, and having achieved the same level of maturity, they started calling for equality. This issue however was not solved immediately as these requirements were blocked by the firm obstacle of social prejudices. ${ }^{52}$ An agreement on the matter of equal-

Brno I 1909-1934. Brno: b.m., 1934, p. 132.

51 AMB, fond R 77 města Brna, N 10, inventární číslo 1575, Výroční zprávy Sokola Brno I 1911-1920 [Annual Reports of Sokol Brno I 1911-1920], 1912, p. 30. This was a unique event and in the 1930's, the abstinence group was set up inspired by the event, which was transformed into the abstinence department of Sokol Brno I on 25 January 1931, see AMB, fond R 77 města Brna, N 10, inventární číslo 1577, Výroční zprávy Sokola Brno I 1931-1934 [Annual Reports of Sokol Brno I 1931-1934], p. 89-90.

52 The Moravian-Silesian župa was the first in the whole CSC where equality of women with men was recognized in Sokol. Anna Vodová was working there in the position of Chief from 
ity was reached only at the extraordinary General Assembly on 16 May 1914 where women were granted the right to vote with proportional representation. Even though this solution was not implemented thoroughly, still a basis for development of women within the union had been agreed. Almost 50 years had thus passed before Tyrš's wish became true. ${ }^{53}$ Jožka Havlíková-Ptáčková was the first Chief elected by the General Assembly on 21 February 1915.

Women never ceased to self-educate themselves during the entire first phase (solving the issue of equality with men). Based on the acquired knowledge, they concluded that not all equipment is suitable for women, which was the first step in the development of Sokol physical exercises for women. They selected swing exercises, hang exercise, balance exercise, they opted for club-exercises instead of weightlifting, they were perfecting jumping over the rope and applying their talents in floor exercises and dance. And from there it was just a small step into the new era of the history of Sokol physical exercises for women. ${ }^{54}$

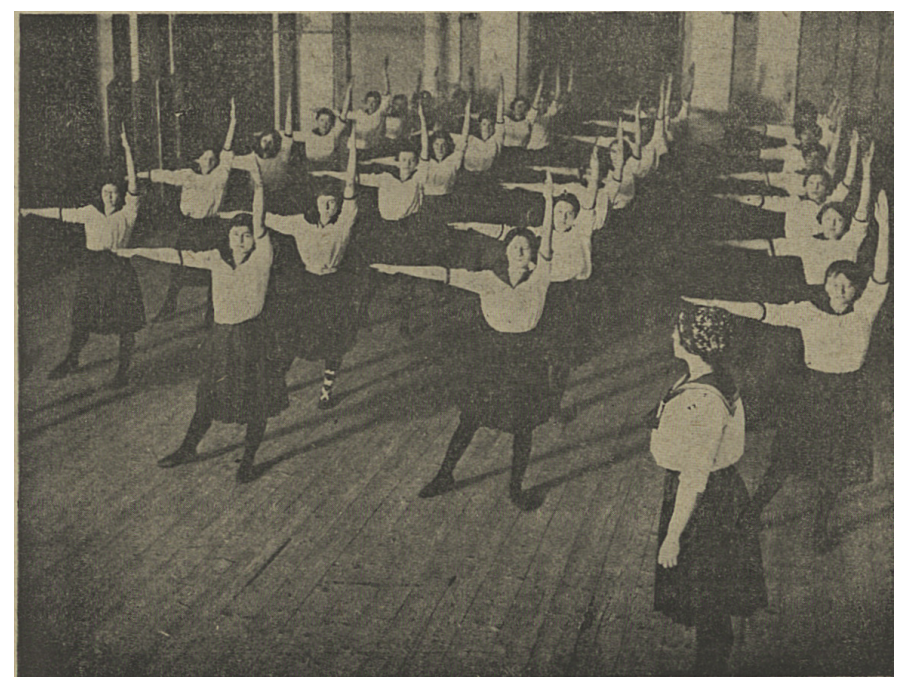

A3 Exercises of female juniors of Brno I in 1915. AMB, fond R 77 města Brna, N 10, inventární číslo 1575, Výroční zprávy Sokola Brno I 1911-1920 [Annual Reports of Sokol Brno I 19111920], 1915, s. 22. Sokol Brno I. during the war. Výroční zprávy odboru tělesné výchovy Sokola Brno I [Annual reports of the physical education union Sokol Brno I] 1915-1918, s. 9. During the war years 1915, 1916, 1917, 1918.

1904. For more see VODOVÁ, ref. 49, p. 127-129.

53 SAK, ref. 8, p. 80-81 compare with Schůtová, ref. 8, p. 72.

54 BABÁKOVÁ, ref. 42, p. 123. 
Before the onset of the world conflict and during the first years of war, women were improving their knowledge at lectures by Augustin Očenášek and Karel Pospíšil in Prague. It was thus men again who were showing the new route. In the period just before the war, women had the opportunity to demonstrate their technical competence, but also organizational and leadership skills as seen at the slet in Brno where the women's units were led by Eliška Roudná. The memorable slet in 1914 was prepared by the technical department with participation of Mrs. Alexová, Jožka Havlíková, Zorka Klossová, who was the chief of the Rastislavova župa at that time, Arna Řeřichová and Antonie Štuchalová. Marie Černá was in the ceremonial committee, Jožka Havlíková in the youth department and Marie Mezerová in the accommodation department. ${ }^{55}$

$* * *$

However, the war interrupted the slet organized at that time as well as the promising development of the women's unit. Women soon had the opportunity to pay back what they learned earlier, and so they undoubtedly did when working tirelessly in the positions of their former teachers. They were leading the women's units, but also helped to work with pupils as the male instructors' team was not able to cover everything on its own. ${ }^{56}$ Women participated in organizing of the Sokol Aid Event aimed at providing supplies of all necessities to the military at the front and in the rear. They also helped with the setting up of the Sokol military hospital in the gymnasium of Sokol Brno II and organized a beneficial event in the National Theatre (5 December 1914) which, being a success, was repeated a week later. Those were the contributions of Sokol women during the war years, trying to divert the attention of the authorities from Sokol work and helping to save the union from dissolution. ${ }^{57}$

It is a paradox that women first had the opportunity to work independently during World War I as they had to replace men serving in the war in various po-

55 AMB, fond R 77 města Brna, N 10, inventární číslo 1575, Výroční zprávy Sokola Brno I 1911-1920 [Annual Reports of Sokol Brno I 1911-1920], 1914, p. 12; BABÁKOVÁ, ref. 42, p. 124. For more see ČEJKA, Jiří. Sokolský slet v Brně roku 1914 [Sokol slet in Brno in 1914]. In Forum Brunense: sbornik praci Muzea města Brna. Brno: Muzeum města Brna, 1996, p. 139-148. ISBN 809019690; ČEJKA, Jiří. Brněnský sokolský slet roku 1914 [The 1914 Brno Sokol slet]. In První světová válka a česká společnost. Brno: Masyrykova univerzita, 1994, p. 62-66. ISBN 8021010517.

56 SCHŮTOVÁ, ref. 8, p. 72; WAIC, ref. 4, p. 97-99.

57 AMB, fond R 77 města Brna, N 10, inventární číslo 1575, Výroční zprávy Sokola Brno I 1911-1920 [Annual Reports of Sokol Brno I 1911-1920], 1914, p. 18-19. Even though the Sokol headquarters of the CSC was dissolved by a resolution of k.k. Ministry of Interior on 24 November 1915, the activities of Sokol župas and majority of unions continued. WAIC, ref. 4, p. 98-99. 
sitions within Sokol. In 1916, women had for the first time a majority at the General Assembly (61:31). ${ }^{58}$ Throughout the war, the functioning of the union was maintained only due to enormous efforts of the remaining members, in particular the hard work of women, and despite the official ban of exercising for pupils. After the creation of Czechoslovakia, the Sokol organization focused its forces on organizing of the VII. Pan-Sokol slet in 1920. Thus, after the war, women became involved in organizing of the slet, started to work in all sections of the Sokol field of activity and were included in all units and teams. Taking care of the union became easier for women once men returned from the war. New directions in physical education were quickly appearing, women liked to take these on board and were soon able to master them. Swimming, games, rhythmic exercises and floor exercises became more widespread at that time. Women's skills were becoming more visible also at competitions. The performance of women at the VII. Pan-Sokol slet presented three novelties: rhythmic floor exercises, a performance by juniors and competitions of women and juniors. At the rally competition of the Czechoslovak Sokol Community, the senior department team won the 1st place and Štěpánka Adamová became Champion of Czechoslovak Sokol Community. In 1923, at an in-between-slets competition of the Czechoslovak Sokol Community, Ludmila Pásková became Champion. The in-between-slets competition of the Czechoslovak Sokol Community in 1928 was also a success for Brno women who won seven first places, five second places and four third places there, out of which ten belonged to Ludmila Sychrová, who was awarded six first places, three second places and one third place for her performance. ${ }^{59}$

One interesting fact - already in the first year after the war, the use of undignified salutes such as "kissing your hand, my lady" was banned, as they contained unnecessary greetings based on the perception at that time. Smoking by women in Sokol unions was declared unacceptable. In the spring of 1920, the women's instructors team of the Czechoslovak Sokol Community approved the proposal to organize training for female instructors and compulsory schools for assistants and instructors were set up. In January 1922, women participated for the first time in instructor examinations of the Czechoslovak Sokol Community. The examination consisted of several parts: written part, exercises, terminology, oral part and leadership examination. Following a complaint from a female instructor that training women related to a low or average level of students in instructor schools, it was decided that codes would be amended for all schools and in parti-

58 AMB, fond R 77 města Brna, N 10, inventární číslo 1575, Výroční zprávy Sokola Brno I 1911-1920 [Annual Reports of Sokol Brno I 1911-1920], 1916, p. 22.

59 WAITOVÁ, ref. 14, p. 574; SCHŮTOVÁ, ref. 8, p. 73; HLADÍK, Pavel. Umístění českých a československých sportovkyň na významných zahraničních i domácích soutěžích do roku 1938. In SCHU゚TOVÁ - WAIC, ref. 3, p. 166. ISBN 8070361581. 
cular for instructor examinations that should be more demanding in the future. ${ }^{60}$ At the end of the 1920s, women proved again that they were indispensable for the community life. This could be seen in particular in the context of exercising premises for the union. At the beginning of the 1890s, there was an urgent need in Sokol Brno to find a solution to the problem of lack of their own premises for exercising that lasted several years. Even though Sokol found refuge in the newly founded Besední dům building from 1872, still the fact that the oldest Sokol union in Moravia did not possess its own sokolovna hall was seen as detrimental for its reputation. The Cooperative for building of a gymnasium for the physical education union Sokol in Brno was therefore founded already in 1890 with the objective of building its own sokolovna. Several architectural designs were prepared in the period 1905-1907 that placed the sokolovna into the garden of the so called Sokol House in the current Lidická Street, but the project was never implemented. ${ }^{61}$

It was thus the situation in the newly created Czechoslovak Republic that brought about new opportunities for the union. The inspection of a land plot in today's Kounicova Street was carried out at the end of 1918 and the land was bought for the purpose of building a gymnasium and a summer training ground already at the beginning of 1919. The outdoor stadium was built in 1922 using the design of architect Miroslav Kopřiva and subsequently the long-awaited sokolovna building designed by Jindřich Kumpošt and Miloš Laml was built in the years 1927-1929.

The development of Sokol Brno I was secured by building of the Stadium and this was perceived as very symbolic, in particular by the older generation. Older female members of Sokol Brno I decided to offer a new flag to the union on the occasion of the opening of the Stadium as an attribute of Sokol integrity and now also national integrity.

The Sokols ordered artistic and architectonic projects mostly from members of their own union, which made sense both from the points of view of ideology and economy. Emílie Ešnerová, member of the women's instructors team, asked Professor Bohumil Babánek, teacher at Česká státní průmyslovka (specialized Czech industrial secondary school), to prepare the design for a new flag. It remains unknown why he was selected for designing the flag.

In the past, it was habitual for the flag to be donated by female members of Sokol unions who would then in most cases become mothers or godmothers of

60 SCHŮTOVÁ, ref. 8, p. 75-76.

61 DOLEŽEL, ref. 22, s. 25-34. Regarding the stadium of Sokol Brno see ČERVENÁ, ref. 30, p. 181-205. 
the flag, and the same approach was applied in this case as well. All the costs related to acquisition of the new flag were covered by member of the union Luisa Šílená, widow of advocate and Reichsrat deputy Václav Š́lený, from her own resources and she thus logically became the mother of the flag. ${ }^{62}$

The author presented his design for assessment in November 1928 first to the women's instructors team and then also to the union's Committee. The Administrative Committee requested another design be prepared by architect Evžen Škarda for the purpose of comparison. ${ }^{63}$ In January of the following year, the flag could be presented also to the donor, and a month later, Luisa Š́lená sent the amount of 10,000 korunas to the union to have the flag made.

Building of the stadium led to rapid development in the number of female Sokol members, but also of the whole union. The dream from the pre-war period came true. The numbers of female instructors were growing as well as the amount of work related to their training. As already mentioned, independent schools were being organized for them in the union and in the župa, but training was also delivered in schools of the Czechoslovak Sokol Community. In parallel with progress in physical education activities, general and also specialized educational training was delivered. This meant above all training the members for individual types of exercises: rhythmic physical education, games, skiing, skating, swimming and floor exercises; the number of members particularly trained for leadership of female pupils, juniors and older women thus increased. ${ }^{64}$

The scope of female work in the union is demonstrated by the following figures. In 1910, there were ten women in the instructors' team, but in 1933 there were already fifty-six women there. The team of female pupils had 23 members when founded in 1921, and twelve years later there were already sixty of them. At the end of 1909, there were 136 registered members, 56 juniors and 137 pupils. The overall number of female members of Sokol Brno in 1933 was 537 women, 167 juniors and 592 pupils exercising in twelve departments (four for women, three for juniors and five for pupils). In addition, each unit was exercising separately in the rhythmic section. ${ }^{65}$

The training plans had to be adjusted to the expansion of the unit and its development. Most efforts in drafting of the timetables came from: Anna Vodo-

62 AMB, fond R 77 města Brna, N 10, inventární číslo 1576, Výroční zprávy Sokola Brno I 1921-1930 [Annual Reports of Sokol Brno I 1921-1930], 1929, p. 9-10.

63 DOLEŽEL, ref. 22, p. 27.

64 MZA, fond G 106 města Brna, inventární číslo 39, k. 315; BABÁKOVÁ, ref. 42, p. 125.

65 BABÁKOVÁ, ref. 42, s. 125 compare with 25 let ženského odboru Sokola Brno I [25 years of the women's unit of Sokol Brno I]. In Lidové noviny, year 42, no. 563 from 8 Nov 1934, p. 6. 
vá, Milada Janošová, Zorka Klossová, Věra Elgartová-Jílková, Amalie Babáková-Hejtmánková, Milada Fritscherová for women; Marie Špačková, Anežka Petrlová-Kepáková, Marie Hošková, Marie Kolíbalová-Potočková for juniors; Marie Benešová, Adéla Lorencová and Marie Kinterová-Krejčová for pupils.

Women did not focus merely on drafting of these training plans, but also directed their energy towards creating physical exercise routines, intended for various competitions and races ( 22 women during the followed period). The authors of the routines participated among others in podium competitions of the Czechoslovak Sokol Community and in 1923, they received the 2nd prize for the routine "Club-exercising" of the authors' duo Ludmila Pásková and Žofie Ráboňová, 3rd prize for the routine "Women's nine" from Andy Šartová. The routine of Ludmila Pásková and Žofie Ráboňová "Club-exercising" was accepted for the group exercises of the women's team for the excursion of Czechoslovak Sokol Community to Strasbourg in 1925. At the second in-between-slets competition of the Czechoslovak Sokol Community in 1928, the union received the 2nd place for the routine of Amalie Hejtmánková-Babáková and Marie Hýlková "Rhythmic exercises with rods" with accompanying music by Karel Matějovec. The ninth (IX.) Pan Sokol slet meant 2nd prize for the routine of Amalie Babáková "Light-athletic floor exercises" with music by Oldřich Harfl. Věra Němcová won the competition in group exercises of women's teams, Czechoslovak Sokol Community, at the first international competition in Budapest held on 2 June $1934 .{ }^{66}$

During the followed period 1902-1934, there were eleven Chiefs in total leading the women's unit:

$\begin{array}{ll}\text { 1902-1903 } & \text { Krista Trávničková, Chief } \\ \text { 1904-1908 } & \\ 1909-1912 & \text { Anna Vodová, Head of Women's Unit } \\ \text { 1914-1918 } & \text { Marie Mezerová, Head of Women's Unit } \\ 1919 & \text { Matylda Moudrá-Schafhauptová, Chief } \\ 1920 & \text { Zorka Klossová, Chief } \\ 1921-1923 & \text { Anna Moudrá, Chief } \\ 1924 & \text { Marie Dokoupilová, Chief } \\ 1925-1929 & \text { Marie Hýlková, Chief } \\ 1930 & \text { Libuše Mášová-Jelínková, Chief } \\ 1931-1934 & \text { Amalie Hejtmánková-Babáková, Chief. }\end{array}$

66 MZA, fond G 106 města Brna, inventární číslo 39, k. 315; BABÁKOVÁ, ref. 42, p. 126. 
During the same period, 21 women took turns in leading the women's section, 20 women in the juniors' section and 30 women in the pupils' section. The longest serving leaders of the women's unit were Amalie Hejtmánková-Babáková (10 years), Zorka Klossová and Ludmila Pášková (7 years), Arna Řeřichová, Aloisie Zajícová, Anežka Petrlová-Kepáková (4 years), Anna Vodová, Jožka Ptáčková-Havlíková, Milada Janošová, Svatava Gallusová (3 years). ${ }^{67}$

The above-mentioned documents clearly show that aftergaining equality, women did not focus just on physical education itself, but tried to apply their efforts in all areas where it was needed - in educational, economic and organizational activities. The physical education unit Sokol Brno I did not lag behind Prague in the women's emancipation movement and was the leading union in Moravia.

The commemoration of 25 years of activity of Sokol Brno I women was held on 11 November 1934 at an extraordinary General Assembly (10 a.m.) and a physical education event ( 8 p.m.) at the stadium in Kounicova Street with Marie Provazníková, Chief of the Czechoslovak Sokol Community. ${ }^{68}$ She also informed about the jubilee academy of Sokol Brno I women in the Lidové noviny newspaper. ${ }^{69}$

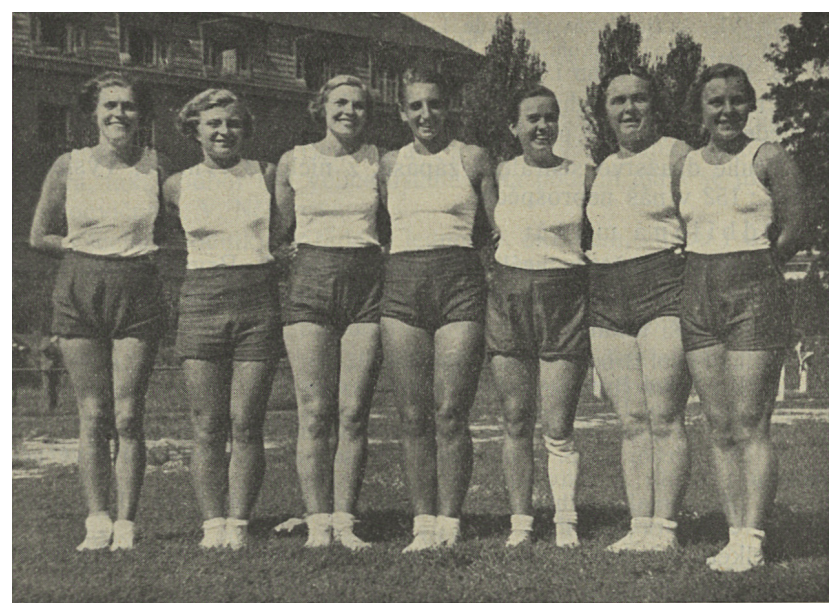

A4 Winning women's team of the CSC basketball competition. AMB, fond R 77 města Brna, N 10, inventární číslo 1577, Výroční zprávy Sokola Brno I 1931-1934 [Annual Reports of Sokol Brno I 1931-1934], 1934, s. 38.

67 BABÁKOVÁ, ref. 42, p. 125-126.

68 Slavnosti [Ceremonies]. In Lidové noviny, year 42, no. 568 from 11 Nov 1934, p. 10. AMB, fond R 77 města Brna, N. 10, inventární číslo 1577, Výroční zprávy Sokola Brno I 1931-1934, [Annual Reports of Sokol Brno I 1931-1934,], 1934, p. 78-79.

69 Jubilejní akademie žen Sokola Brno I [Jubilee women's academia event of Sokol Brno I]. In Lidové noviny, year 42, no. 572 from 13 Nov 1934, p. 4. 


\section{CONCLUSION}

Setting up of the women's unit of Sokol Brno I was a progressive and courageous idea, despite the fact that it only occurred in the 20th century. The delay in founding of the women's unit compared to the date of creation of the Brno union originating already in 1862 was caused by numerous social prejudices.

The women's unit of Sokol Brno I must thus be perceived primarily as the expression of the efforts for general progress, but also efforts for national self-identification within the Monarchy, promotion of the progressive women's movement and development of the Sokol idea. The beginnings of the women's unit were accompanied by some complications, conflicts and misunderstandings. It was also necessary to set up an appropriate relationship with the men's units that would respect the situation and needs of that time.

Finding their position was not difficult just for women, even Sokol itself, created in Brno in 1862, had long-term issues trying to establish itself. Large cities in Moravia (including Brno) were predominantly German at that time, governed by German-speaking town-halls, thus German-speaking associations were given preference. During the period of nationalistic tensions, Sokol in Brno was trying to find its own way, stopping its existence for several times, but it was always quickly re-launched again. Uninterrupted functioning dates from 1877, despite the pressure it still had to face for some time from state and local authority bodies.

The women's unit of Sokol Brno was created in 1902, under the influence of the impression of performances by women gained at the III. Pan Sokol slet in 1901. As in Sokol Brno itself, also the beginnings of the women's unit were not smooth and it was abolished for several reasons in 1904. Women were not even given the opportunity to express their oppinion on the whole situation. The disputes that continued between the members of the administrative committee for several following years were signs of growing doubts about the real level of seriousness of the reasons leading to the abolition of the women's unit. A scenario where the men's unit did not see much significance in the women's unit and thus abolished it at the very first sign of any problems, seems to be likely.

The women's unit was re-launched in 1909 at the proposal of Anna Vodová who fully deserves the denomination of the founder of the unit. It was her efforts, together with only a few co-workers, that built the solid foundations for physical education of women in Sokol Brno I. She trained the instructors, prepared public performances and acted as the best leader of the women's unit for three years. In November 1912, she withdrew from all functions in the women's unit to protest against the union's approach to equality and she became a member of the union in Královo Polo which was part of the Brněnská župa, all this despite the fact that she became the first Chief of Rastislavova župa in that same year. 
The conditions were much better for the unit after its second start and it was progressing well. Voices were raised that started to call for a representation of women in the leadership of Sokol and in its activities in general due to the increasing level of education and professional knowledge of women. That was the beginning of the efforts to achieve equality of the women's unit that lasted until 1914. Despite the growing efforts of the women's unit, the union was trying to put this issue aside, and the increasing tensions led only to the demonstrative departures of several female members, including the already mentioned case of the leader Anna Vodová. Even this protest did not move the union to action and the whole issue kept being postponed until the statement of the Czechoslovak Sokol Community. Finally, the women's unit, assisted by men who were in favour of their issue, achieved the first steps towards equality in May 1914. Despite the fact that some time elapsed before the changes were well implemented in the unions, women became an undisputable part of Sokol during World War I.

1914 was a crucial year for the women's emancipation movement - progress was achieved in the issue of equality with men and women could also prove their skills when organizing the Pan-Sokol slet in Brno. The Brno Sokol slet was summoned for 27-28 June 1914 and was held on the land of the former military training ground in Královo Pole. The performance of women was scheduled after floor exercises by men, but information about the attempt to assassinate the heir to the throne Franz Ferdinand d'Este started to come in and after confirmation thereof, the whole event was closed. During the war that followed, women proved enormous perseverance and hard work, but also female tactics. This allowed them to divert the interest of the authorities from the Sokol activities and save the Brno union from the risk of official dissolution.

It was only the situation in the newly founded Czechoslovak Republic that brought about new opportunities for the Brno union. After the foundation of Czechoslovakia, the Sokol organization focused its efforts on organizing the VII. Pan-Sokol slet in 1920. Sokol Brno I acquired not only the so-long-awaited plot of land, but also its own sokolovna building in the years 1927-1929. In Brno as well, women gradually started to be involved in all sections of the Sokol work and they were accepted into all departments and units. 


\section{EMANZIPATION DER FRAUEN IM SPORTUNTERRICHT ÜBER GESCHICHTE DER FRAUENGRUPPE DES VEREINS SOKOL BRNO I (1902-1934)}

\section{MILENA S T R A C H O V Á}

Der Beitrag analysiert die Anfänge der Emanzipationsbewegung der tschechischen Frauen zu Beginn des 20. Jahrhunderts und zwar in Anbetracht der Beziehung zweier Kulturzentren (Prag und Brünn). Unter anderem erinnert er an die bedeutsame Epoche der Brünner Kulturgeschichte vor dem 1. Weltkrieg. Die Aufmerksamkeit richtet sich insbesondere auf die Turnanfänge der Frauensektionen des Vereines Sokol Brünn I, des größten und ältesten Vereines in Mähren. Die Anfänge der Sokol-Frauensektion, wie auch des Vereines als Ganzes, waren nicht einfach. Nicht nur dass die Stellung von Frauen kompliziert war, auch der 1862 in Brünn entstandene Sokol-Verein war lange Zeit in einer schwierigen Position. Schuld daran trugen vor allem nationale Streitigkeiten, da die großen mährischen Städte (einschließlich Brünn) zu der Zeit deutsch waren, sodass dort logischerweise deutsche Vereine bevorzugt wurden. Der Sokol-Verein suchte sich in Brünn lange seinen Weg, wobei er mehrmals erloschen ist, anschließend jedoch stets bald wieder belebt wurde.

Grundlegend ist für die Frauenemanzipationsbewegung das Jahr 1914, in dem die Frauen einerseits einen Fortschritt in Bezug auf die Gleichberichtigung von Mann und Frau erzielten, außerdem jedoch auch ihre Fähigkeiten beim Veranstalten des in Brünn stattfindenden internationalen Sokol-Treffens (všesokolský slet), das für den Zeitraum vom 27. bis 28. Juni einberufen wurde, unter Beweis stellen konnten. Nach dem Turnauftritt von Männern sollten auch Frauen an die Reihe kommen, zu dem Zeitpunkt verbreiteten sich allerdings bereits Nachrichten vom Attentat auf den Thronfolger Franz Ferdinand von Österreich-Este. Nachdem diese bestätigt wurden, wurde die Veranstaltung beendet. In dem darauffolgenden Krieg gelang es den Frauen, die Aufmerksamkeit der Behörden von den Aktivitäten des Sokol-Vereines abzuwenden, wodurch sie den Brünner Verein vor dessen behördlicher Auflösung bewahrten. Bis zum Ende des ersten Weltkrieges wurden die Frauen zu einem unbezweifelbaren Bestandteil des Sokol-Vereins.

Mgr. Milena Strachová, Ph.D.

Katedra společenských věd a managementu sportu

Masarykova univerzita, Fakulta sportovních studií

Kamenice 5, 62500 Brno

Česká republika

e-mail: strachova@fsps.muni.cz 